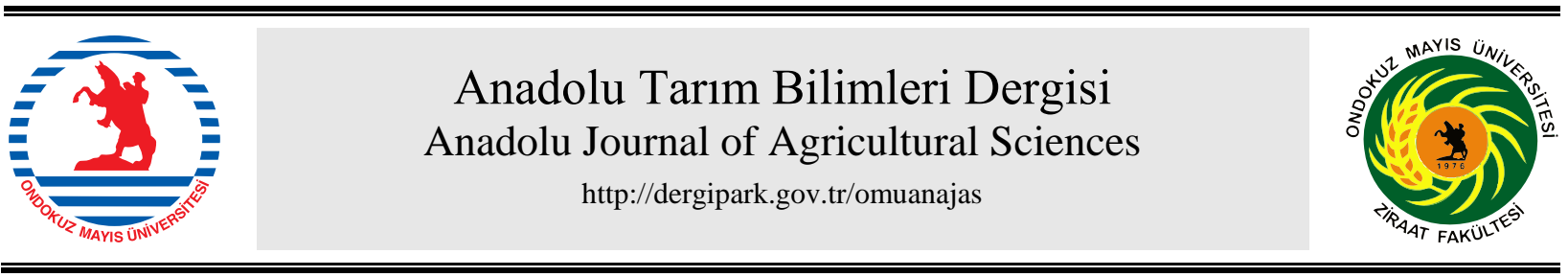

Araştırma/Research

\section{Afyonkarahisar ve Isparta illerindeki buğday üretim alanlarında Barley yellow dwarf virus-PAV ve Barley yellow dwarf virus-MAV' in belirlenmesi}

Anadolu Tarım Bilim. Derg./Anadolu J Agr Sci, 34 (2019) ISSN: 1308-8750 (Print) 1308-8769 (Online) doi: $10.7161 /$ omuanajas.404611

\author{
Handan Çulal Kılıç*, Nejla Yardımcı, Durkadın Toman \\ Isparta Uygulamalı Bilimler Üniversitesi, Tarım Bilimleri ve Teknolojileri Fakültesi, Bitki Koruma Bölümü, Isparta \\ *Sorumlu yazar/Corresponding author: handankilic@ sdu.edu.tr
}

Geliş/Received 12.03.2018 Kabul/Accepted 03.12.2018

\begin{abstract}
ÖZET
Arpa Sarı Cücelik Hastalığı, tüm dünyada buğday üretim alanlarında en yaygın ve ekonomik kayıp oluşturan viral hastalıklardan biridir. Bu hastalığa Luteoviridae familyasında yer alan Barley yellow dwarf virus türlerinden (BYDVs) herhangi biri neden olmaktadır. Bu çalışmada, Afyonkarahisar ve Isparta illerindeki buğday üretim alanlarında Barley yellow dwarf virus PAV (BYDV-PAV) ve Barley yellow dwarf virus MAV (BYDV-MAV)'ın belirlenmesi amacıyla 2016 yılı buğday üretim döneminde virüs belirtisi gösteren 94 adet bitki örneği toplanmıştır. BYDV-PAV ve BYDV-MAV'ın varlığı DASELISA (Double antibody sandwich enzyme linked immunosorbent assay) test yöntemi ile belirlenmiştir. DAS-ELISA test sonuçlarına göre 94 örneğin 68 adedinde \% 72.3 oranında BYDV-PAV ve 2 örnekte ise \% 2.1 oranında BYDV-MAV tekli enfeksiyonları belirlenmiştir. Örneklerin sadece 4 adedinde $\% 4.2$ oranında her iki virüsün karışık enfeksiyonu tespit edilmiştir.
\end{abstract}

Detection of Barley yellow dwarf virus-PAV and Barley yellow dwarf virus-MAV in wheat production areas of Isparta and Afyonkarahisar provinces

\title{
ABSTRACT
}

Barley yellow dwarf disease is the most widespread viral disease causing economic losses in wheat areas all around the world. Any species of Barley yellow dwarf viruses (BYDVs) of the Luteoviridae family causes the disease. In this study, Barley yellow dwarf virus PAV (BYDV-PAV) and Barley yellow dwarf virus MAV (BYDV-MAV) were identified in wheat growing areas of Afyonkarahisar and Isparta provinces, a total of 94 samples were collected from wheat plants exhibiting virus-like symptoms in 2016 growing season. BYDV-PAV and BYDV-MAV were determined by using DASELISA (Double antibody sandwich enzyme linked immunosorbent assay). The result of DAS-ELISA revealed that 68 out of 94 samples at the rate of $72.3 \%$ were found to be infected with BYDV-PAV and two of them at the rate of $2.1 \%$ had BYDV-MAV. The mixed infection of both viruses with a rate of $4.2 \%$ was detected in only four of the samples tested.

Anahtar Sözcükler:

Buğday

BYDV

MAV

BYDV-PAV

DAS-ELISA

\section{Giriş}

Temel gida olan ekmeğin hammaddesini oluşturan kışlık ekmeklik buğday (Triticum aestivum L.), oldukça önemli bir üründür. Türkiye'nin birçok bölgesinde yetişebilen Graminea familyasına ait olan buğday, besin içeriği ile insan beslenmesi yönünden önemli olup hayvansal üretimde besin kaynağı olarak ve çeşitli endüstriyel alanlarda kullanılmaktadır (Kızılaslan, 2004).

Dünyanın çoğu ülkesinde ve Türkiye'nin neredeyse her bölgesinde buğday üretimi yapılmaktadır. Dünya tahıl üretimi göz önüne alındığında buğday ve arpada birinci sırada Avrupa Birliği, mısırda ise birinci sırada, $A B D$ yer almaktadır. 127 milyon ton buğday üretimi ile ikinci sırada bulunan Çin'i, 89 milyon tonla Hindistan izlemektedir. Türkiye ise, dünya buğday üretimi içerisinde ortalama 20 milyon tonluk rekoltesi ile $\%$ 3.16'lık bir paya sahip bulunmaktadır (Anonymous, 2015).

Bitkisel üretimde verim ve kaliteyi etkileyen en önemli faktörlerin başında hastalık ve zararlıların neden olduğu verim kayıpları ve yabancı otların rekabeti gelmektedir. Üretimi yapılan diğer kültür bitkileri gibi 
tahıl türleri de bu etmenlerden etkilenmektedir. Dünya'da ve Türkiye'de ekiliş ve üretim bakımından ilk sırada yer alan buğday bitkisinde görülen çok sayıdaki hastalık etmenleri, önemli düzeyde ekonomik kayıplara yol açmaktadır.

Buğdayı etkileyen hastalıklar arasında virüs hastalıklarının önemli bir yeri vardır. Buğday, çok sayıda virüsün doğal konukçusudur. Brunt ve ark., (1996) buğdayın 55 virüse karşı duyarlı olduğunu ve Wiese (1987) ise 30 civarında virüsün buğdayı doğal olarak enfekte ettiğini bildirmişlerdir.

Buğdayda enfeksiyona neden olan viral hastalık etmenleri, bitkilerin yapraklarında beneklenme, çizgi mozayik ve sararma şeklinde klorozun yanısıra nekroz, cücelik ve rozetleşme belirtilerine neden olmaktadır. Özellikle yaprak renginde değişikliğe neden olan bazı simptomlar beslenme ve abiyotik etmenlerin oluşturduğu simptomlar ile karıştırılabilmektedir. Bundan başka, aynı bitkide enfeksiyona neden olan birçok virüsün bulunma durumuna siklıkla rastlanmaktadır (Irwin ve Thresh, 1990).

Gelişmekte olan ülkelerde buğday üretim alanlarında yaygın olarak görülen virüs hastalıkları, Barley yellow dwarf virus (BYDV), Soilborne wheat mosaic virus (SWMV) ve Wheat yellow mosaic virus (WYMV)'leridir. Bunların dışında Cereal yellow dwarf virus (CYDV-RPV), Brome mosaic virus (BMV), Wheat dwarf virus (WDV), Barley stripe mosaic virus (BSMV) ve Wheat streak mosaic virus (WSMV)'leri de sık görülen virüs türleri arasında yer almaktadır (Hofmann ve Kolb, 1998; Duveiller ve ark., 2007; Gaunce ve Bockus, 2015).

Geçtiğimiz yüzyılın ortalarında Oswald ve Houston (1951) tarafindan tanılanan Barley yellow dwarf virus (Arpa sarı cücelik virüsü) ile ilişkili olan virüsler, pozitif anlamlı tek sarmal RNA içeren 24-25 nm çapında ikozahedral yapıda partiküle sahip, Luteoviridae familyasının Luteovirus cinsleri içinde yer alan türlerdir.

Buğday başta olmak üzere diğer tahıl türlerini de aynı oranda etkileyen virüsler arasında yer alan BYDVs, dünya çapında yaygın olarak görülen ve ekonomik açıdan önem taşıyan tahıl türlerinin en yıkıcı virüsleri olarak ifade edilmektedir (Kennedy ve Connery, 2005). Daha önce vektör yaprak biti türlerine özgü olarak ırk düzeyinde tanımlanan bu virüsler, günümüzde tür düzeyinde isimlendirilerek sinıflandırılmışlardır (Domier, 2012). Sözkonusu virüslerin tüm genom sekansları mukayese edilmiş ve bu virüslere kollektif olarak "Yellow dwarf viruses (YDVs)" adı verilerek gruplandırılmışlardır (Kruger ve ark., 2013). Buna göre Luteovirus cinsi içerisinde, BYDV-GAV, BYDVMAV, BYDV-PAV, BYDV-PAS, BYDV-SGV olmak üzere beş tür yer almıştır. Tahıllarda sarı cücelik hastalığına sebep olan Cereal yellow dwarf virus RPV (CYDV-RPV) ve Cereal yellow dwarf virus RPS (CYDV-RPS), iki yeni tür olarak Polerovirus cinsi içerisine yerleştirilmiştir. Bunlardan CYDV-RPV, eskiden BYDV-RPV olarak isimlendirilen türdür. Yine eskiden BYDV-GPV olarak adlandırılan virüsün, sadece buğdayda sarı cücelik hastalığına neden olduğu saptandıktan sonra yeni tür adı Wheat yellow dwarf virus-GPV (WYDV-GPV) olarak değiştirilmiştir. Ayrıca eskiden BYDV-RMV olarak bilinen virüsün yeni adı Maize yellow dwarf virus-RMV (MYDVRMV) olarak önerilmiştir (Kruger ve ark., 2013). Böylelikle, genom analiz sonuçlarına göre, gerek WYDV-GPV gerekse MYDV-RMV; CYDV-RPV ve CYDV-RPS ile birlikte Polerovirus cinsinde yer almıştır (Kruger ve ark., 2013). Tahıl sarılık virüslerinin bu son sinıflandırmaya göre 9 farklı türü bulunmaktadır. $\mathrm{Bu}$ sınıflandırma sadece virüsü taşıyan yaprak bitleri türüne göre değil virüslerin genom dizilerindeki farklılıklara göre yapılmıştır (İlbağı, 2017).

BYDV ile enfekte olan bitkilerde kök gelişimi zayıflamakta, sürgün sayısı azalmakta ve bitkiler şiddetle bodurlaşmaktadır, yapraklarda ise sararma ve kızarma şeklinde renk değişimleri gözlenmektedir. Buğdayda, yaprak ucundan tabana ve kenardan merkeze doğru sarı ve bazen kırmızı tonlarındaki renk değişikliği en tipik belirtilerindendir. Şiddetli hastalıkta büyüme geriliği, kısırlık ve boş dane oluşumu ortaya çıkabilmektedir (Perry ve ark., 2000). Wiese (1987), virüsün buğdayda \% 5-25 arasında değişen oranlarda kayıplara yol açtığını bildirmiştir. BYDV enfeksiyonları nedeniyle buğdayda $\% 46$, arpada $\% 25$ ve yulafta $\% 15$ kadar verim kayıpları ortaya çıkabileceğini bildirilmiştir (Kaddachi ve ark., 2014).

ABD'nin Idaho Eyaleti'nde BYDV epidemisi sırasında, sonbaharda ekilmiş buğdaylarda ortaya çıkan $\%$ 70-\%100 verim kayıplarının BYDV'den kaynaklandığı ifade edilmiştir (Marshall and Rashed 2014). Ancak, tarla koşullarında doğal BYDV enfeksiyonunda ortalama verim kayıplarının \% 11 ile \% 33 arasında ortaya çıkabileceği bildirilmektedir (Kaddachi ve ark., 2014).

Mekaniksel olarak ve tohumla taşınmayan Barley yellow dwarf luteovirus (BYDV), afit vektörleri ile persistent biçimde üretim sezonunda tahıllara taşınıp yayılmaktadır (Thackraya ve ark., 2009). BYDVs, 15 farklı cinsten en az 25 afit türüyle taşınmaktadır (Halbert and Voegtlin 1995). BYDV-MAV Macrosiphum (Sitobion) avenae; BYDV-PAV Rhopalosiphum padi ve Sitobion avenae ile taşınmaktadırlar (Deligöz ve ark., 2011; Fidan ve ark., 2014).

Genel olarak, BYDVs içerisinde BYDV-PAV şiddetli simptomlara yol açarken, BYDV-MAV orta şiddetli hafif belirtilere neden olmaktadır. BYDVs'ler s1klıkla aynı bitkide birarada bulunabilmektedir.

$\mathrm{Bu}$ çalışma, 2016 yılının kış ve bahar aylarında Afyonkarahisar Merkez ve Sandıkli; Isparta'nın Gönen ve Yalvaç ilçelerinde buğday tarlalarında yaygın bir şekilde şiddetli cücelik ve sararma belirtilerinin bulunduğuna dair üreticilerden gelen şikayetler üzerine araştırılmıştır. Aynı dönemde Türkiye'nin farklı buğday üretim alanlarında da Barley yellow dwarf viruses (BYDVs) epidemiye neden olmuştur. 


\section{Materyal ve Yöntem}

Sürvey çalışmaları esnasında alınan kışlık buğday örneklerindeki simptomlar gözlemlendiğinde etmenin BYDV olabileceği şüphesini doğurmuştur. Bitkilerin kök gelişiminde zayıflama, kardeşlenen sürgün sayısında azalma ve bitkilerde şiddetli cücelik belirtileri görülmüştür. Ayrıca yapraklarda ise sararma ve kızarma şeklinde renk değişimleri gözlenmiştir. Enfekteli buğday üretim alanlarında ve bitkilerde gözlemlenen simptomlar gösterilmiştir (Şekil 1,2).

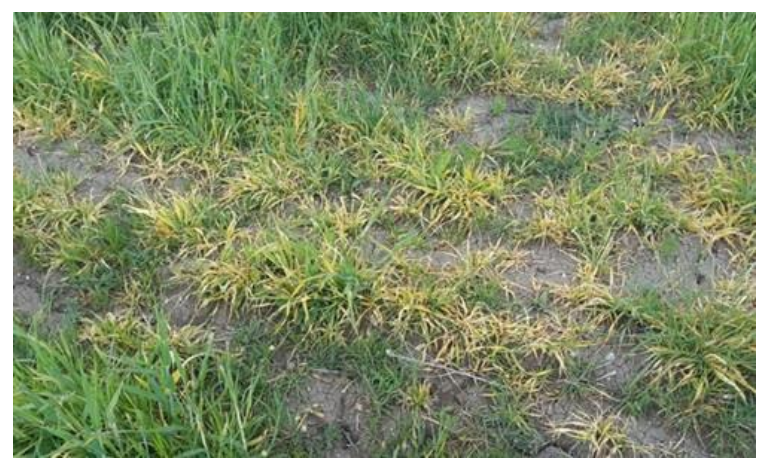

Şekil 1. Buğday bitkilerinde gözlenen şiddetli cücelik ve sararma belirtileri



Şekil 2. Buğdayda kök gelişmesinde azalma ve yapraklarda sararma belirtileri

2016 y1lı üretim döneminde Afyonkarahisar ve Isparta illerindeki buğday üretim alanlarından bitkide cücelik, yapraklarda sararma ve kızarıklık belirtileri sergileyen bitki örnekleri alınmıștır. Afyonkarahisar'dan 76, Isparta'dan 18 olmak üzere toplam 94 yaprak örneği toplanmıştır.

Araziden toplanan bitkide cücelik, yapraklarda sararma ve kızarıklı belirtisi sergileyen yaprak örnekleri BYDV'nün en yaygın türleri olduğu bildirilen (Ilbağı, 2003; Ilbağı ve ark., 2005; Pocsai ve ark., 2003)
BYDV-PAV ve BYDV-MAV için DAS ELISA yöntemi ile test edilmişlerdir. Bu amaçla BYDV-PAV ve BYDV-MAV türlerine özgü spesifik antiserumlar (Agdia, Inc., Elkhart, IN) kullanılmış ve yöntem DASELISA kit içerisinde belirtilen prosedüre göre gerçekleştirilmiştir.

Substrat ilavesinden 60 dakika sonra mikropleyt okuyucusunda (Versamax tunable, Microplate reader) $405 \mathrm{~nm}$ dalga boyunda absorbans değerleri elde edilmiştir. Her bir virüs için negatif kontrollerin absorbans değerlerinin 2 katı ve daha fazla değer veren örnekler pozitif olarak kabul edilmiştir (Ilbağı, 2017).

\section{Bulgular ve Tartışma}

Alınan yaprak örneklerine uygulanan DAS ELISA sonucunda Afyonkarahisar ve Isparta illerindeki farklı buğday üretim alanlarında 2016 üretim döneminde epidemik boyuta ulaşan etmenin BYDVs'nin BYDVPAV ve BYDV-MAV türleri olduğu saptanmıştır. Buğday örneklerinin \% 72.3'ünün (68 adedinin) BYDV-PAV, ve \% 4.2'sinin (4 adedinin) ise BYDVPAV+ BYDV-MAV türlerinin birlikte karışık enfeksiyon oluşturdukları saptanmıştır. Test edilen örneklerin sadece 2 adedinde (\% 2.1) tekli BYDV-MAV enfeksiyonuna rastlanmıştır. Böylece 94 simptomatik virüs enfekteli buğday yaprak örneklerinden toplam 74 adedinin yani \% 78.7 oranında BYDVs'ler içerdikleri saptanmıştır. DAS-ELISA testi sonuçlarına göre; BYDV-PAV örnek alınan tüm bölgelerde tespit edilirken, BYDV-MAV'ün tekli enfeksiyonu 2 örnekle yalnızca Afyonkarahisar Merkez ilçede belirlenmiştir. BYDV-PAV+BYDV-MAV ikili enfeksiyonu ise Isparta'nın Yalvaç ilçesinde tespit edilmiştir (Çizelge $1)$.

İlbağı ve Çıtır (2004) BYDV ırklarını belirledikleri çalışmalarında, yaygın olarak PAV, RMV, MAV, SGV ve RPV'yi tespit etmişler ve bunlar arasında BYDVPAV'ın baskın olduğunu ifade etmişlerdir.

Tekirdağ ilinde buğdaylarda cücelik belirtisi gösteren bitki örneklerinin \% 25'inde BYDV-MAV, \% 22.3'ünde BYDV-PAV saptanmıştır (Köklü, 2004). Yine, kışlık arpada sararma, beneklenme ve çizgi simptomu gösteren bitki örneklerinin ELISA testi sonucunda, \% 22.41'inde BYDV-PAV ve \% 17.93'ünde ise BYDV-MAV enfeksiyonu tespit edilmiştir (Köklü, 2004).

Samsun ilinde 2006 yılında yürütülen başka bir çalışmada ise toplanan 154 buğday bitki örneğinde; 5 örnekte BYDV-PAV (\% 3.4), 3 örnekte BYDV-MAV $(\%$ 2) ve 1 örnekte ise BYDV-PAV+MAV ikili enfeksiyonu ( $\%$ 0.7) saptanmıştır. BYDV-PAV'ın BYDV-MAV'a göre daha yaygın olduğu belirlenmiştir (Erkan ve Kutluk Yılmaz, 2009). İlbağı ve ark., (2005) tarafindan Edirne, Tekirdağ ve Kırklareli illerinde hububat alanlarındaki virüs hastalıklarının belirlenmesi ile ilgili yapılan çalışmada 90 örnekten 63'ünün BYDV-PAV virüsü ile enfekteli olduğu DAS-ELISA ve RT-PCR yöntemleri ile tespit edilmiştir. Ayrıca bölgede 
yoğun olarak Rhopalosiphum padi (L.)' nin varlığı belirlenmiştir. Yine aynı bölge de 2017 yılında yapılan çalışma da DAS-ELISA ve RT-PCR testleri sonucunda 187 adet örnekten 89 adedinde BYDV-PAV; 30 örnekte \% 16.04 oranında CYDV-RPV ve 4 örnekte ise \% 2.14 oranında BYDV-MAV virüsleri saptanmıştır. Fidan ve ark., (2014), Kuzey Kıbrıs Türk Cumhuriyeti tahıl üretim alanlarında BYDV-PAV, BYDV-MAV ve CYDV-RPV virüslerini DAS-ELISA yöntemi ile belirlemişlerdir. Ayrıca BYDV-PAV ve BYDV-MAV ırklarının Rhopalosiphum padi (L.) ve Sitobion avenae (F.) türlerinin bünyesindeki varlıkları RT-PCR yöntemi ile ortaya konulmuştur. Doğu Anadolu Bölgesindeki buğday alanlarında yapılan farklı bir çalışmada da BYDV-PAV, BYDV-SGV ve CYDV-RPV'nin bu bölgedeki varlığı ilk kez belirlenmiştir (Usta ve ark., 2016). Çaplan ve Paylan (2016) Ege bölgesi buğday üretim alanlarında BYDV'nin enfeksiyon oranını $\% 9.8$ olarak belirlemişler ve virüsün teşhisinde DAS-ELISA ve RT-PCR yöntemlerini kullanmışlardır.

Çizelge 1. Afyonkarahisar ve Isparta illerinden alınan buğday örneklerinde Barley yellow dwarf virus (BYDV)MAV ve BYDV-PAV'ın bulunma durumuna ait DAS-ELISA sonuçları

\begin{tabular}{lcccc}
\hline Örnek Alınan Yerler & Alınan Örnek Sayıs1 & BYDV-PAV & BYDV-MAV & BYDV-PAV + BYDV-MAV \\
\hline AFYONKARAHISAR & 57 & 45 & 2 & 3 \\
Merkez & 19 & 10 & 0 & 0 \\
Sandıklı & & & & 0 \\
ISPARTA & 11 & 8 & 0 & 1 \\
Gönen & 7 & 5 & 0 & 4 \\
Yalvaç & 94 & 68 & 2 & 4.2 \\
\hline Toplam & & 72.3 & 2.1 & \\
\hline Enfeksiyon Oranı & &
\end{tabular}

Afyonkarahisar'a bağlı Merkez ve Sandıklı ilçeleri ile Isparta iline bağlı Gönen ve Yalvaç ilçelerinde yürütülen bu çalışma sonuçları ile ülkemizin Trakya Bölgesi ve Samsun, Amasya illerinde yapılan çalışma sonuçları kıyaslandığında, araştırma bölgesinde BYDVs'lerinden PAV'ın bulaşıklık oranının oldukça yüksek olduğu (\% 76.6), MAV'ın ise diğer bölgelerle benzer düzeylerde (\% 6.4) olduğu görülmektedir.

BYDV-PAV'in Rhopalosiphum padi (Homoptera: Aphididae) ve Sitobion avenae (F.) (Homoptera: Aphididae) ile BYDV-MAV'in ise spesifik olarak Sitobion avenae ile persistent olarak taşındığı bilinmektedir (İlbağı ve ark., 2013; Fidan ve ark., 2014). Araştırmanın yapıldığı bölgede daha önce yürütülen bir çalışmada buğday üretim alanlarında BYDV'nün etkili vektörlerinden S. avenae ve R. padi' nin varlığı saptanmıştır (Demirözer ve Bilginturan, 2014)

$\mathrm{Bu}$ araştırmada yaprak biti türleri ile taşınma özelliğinde olan BYDV-PAV'nün toplam 72 örnekte (\% 76.6) saptanması, bu virüsün taşınmasında etkili olan $R$. padi ve $S$. avenea'nın bölgede oldukça yoğun olduğunu düşündürmektedir.

Sürvey çalışmaları sırasında gözlenen virüs benzeri simptomların yoğunluğu ve yöredeki üreticilerden gelen şikayetler ve ELISA testi ile belirlenen BYDV enfeksiyon oranları göz önüne alındığında, bölgenin yaprak biti türleri ile taşınan BYDVs ile oldukça yüksek oranda bulaşık olduğu izlenimini vermiştir. Bölgede, çalışmada testlenemeyen diğer buğdaygil virüslerinin de bulunması muhtemeldir. Bölgemizde buğdaygil bitkilerindeki virüs enfeksiyonlarına yönelik herhangi bir çalışma bulunmamaktadır. $\mathrm{Bu}$ nedenle başta epidemiyolojisi karmaşı olan BYDV ve diğer buğdaygil virüslerine ve vektörlerine yönelik olarak daha fazla ve detaylı çalışma yapılması gerekmektedir.

\section{Sonuç}

Buğday çeşitlerinin hiçbiri bu virüse tamamen dayanıklı değildir ancak birkaç çeşit hastalığa daha az duyarlıdır. BYDV kontrolü için kritik zaman bitkinin erken büyüme aşamasındaki dönemidir (Plumb ve Johnstone, 1995). Bu bakımdan, kış ve ilkbahar ekimlerini, yaprak biti popülasyonlarının yoğun olduğu dönemlerle aynı zamana getirmemeye dikkat edilmesi gerekmektedir. Bunun için sonbahar ekiminin mümkün olduğunca geç, ilkbahar ekiminin ise mümkün olduğunca erken yapılması önerilmektedir (İlbağı ve ark., 2005). Ayrıca yöreye uygun çeşitin seçilmesi de BYDVs ile mücadelede önemlidir. BYDV'ne veya vektörlerine karşı dayanıklı ya da tolerant çeşitlerin kullanılması enfeksiyonu kontrol etmek için en umut verici yaklaşımlardır (Cooper ve Jones, 1983).

Son yıllarda moleküler çalışmaların gelişmesiyle beraber dayanıklılık çalışmalarında da bir artı̧̧ meydana gelmiştir (Choudhury ve ark., 2017). Ekmeklik buğday çeşitlerinde virüse dayanıklılık geninin belirlenmesi ile ilgili yapılan bir çalışmada BYDV'e dayanıkı gen belirlenememişken, Anza buğday çeşitinde Bdv1 geni rapor edilmiştir. Başka bir çalışmada da; arpa da Ryd1, Ryd2 ve Ryd3 dayanıklılık genleri tespit edilmiştir. Ancak yapılan çalışmalarda; bu genlerin BYDV'nin bütün izolatları için dayanıklılık sağlamadığı ifade edilmiştir (Singh ve ark., 1993; Ayala ve ark., 2001; Ordon ve ark., 2009). Hem virüs hem de yaprak bitlerine konukçuluk yapmalarından dolayı tahıl yetiştirilen alanlarda bulunan yabancı otlarla mutlaka mücadele edilmelidir. Bunun yanısıra üç yıllık ekim nöbetinin uygulanması da BYDVs'nin mücadelesinde oldukça etkili olmaktadır (Ilbağı, 2017). 


\section{Kaynaklar}

Anonymous, 2015. Toprak Mahsulleri Ofisi, Hububat Bülteni, Sayı: 2015/6.

Blackman R.L., Eastop, V.F., Brown, P.A. 1990. The biology and taxonomy of the aphids transmitting Barley yellow dwarf virus: World perspectives on barley yellow dwarf. In Burnett, P.A. (Eds). CIMMYT, Mexico. pp. 197-214.

Brunt, A.A., Crabtree, K., Dallwitz, M.J., Gibbs, A.J., Watson, L., 1996. Viruses of plants - descriptions and lists from the VIDE database. Wallingford, CAB International. 1484 pp. UK.

Choudhury, S., Hu, H., Meinke, H., Shabala, S., Westmore, G., Larkin, P., Zhou, M., 2017. Barley yellow dwarf viruses: infection mechanisms and breeding strategies. Euphytica, 213: 168

Cooper, J.I., Jones, A.T., 1983. Responses of plants to viruses: proposals for use of terms. Phytopathology, 73: 127-128.

Çaplan, D., Paylan, İ.C., 2016. Ege Bölgesi buğday üretim alanlarında Barley yellow dwarf virus (BYDV)'nin bulunma durumunun ve moleküler özelliklerinin belirlenmesi üzerinde çalışmalar.Uluslararası Katılımlı Türkiye VI. Bitki Koruma Kongresi, 5-8 Eylül, Konya, 554s.

Deligöz,I., Caner, Y.K., Akyol, H., 2011. Samsun ve Amasya illerinde buğday üretim alanlarında enfeksiyona neden olan Barley yellow dwarf virusPAV ve Barley yellow dwarf virus-MAV virüslerinin araştırılması. Bitki Koruma Bülteni, 51(2): 187-193.

Demirözer O., Bilginturan, S., 2014. Türkiye Göller Bölgesi hububat alanlarında bulunan böcek türleri, yayılışları ve yeni bir kayıt. Türkiye Entomoloji Bülteni, 4(1): 3-13.

Domier, L.L., 2012. Family Luteoviridae. In: King, A.M.Q., Adams, M.J., Carstens, E.B., Lefkowitz, E.J. (Eds.). Virus taxonomy, 9 th report of the international committee on taxonomy of viruses. Elsevier, Academic Press, San Diago CA, USA. pp. 1045-1053.

Duveiller, E., SinghJulie R.P., Nicol, M., 2007.The challenges of maintaining wheat productivity: pests, diseases, and potential epidemics. Euphytica, 157(3): 417-430.

Erkan, E., Kutluk Yılmaz, N.D., 2009. Samsun ilinde buğday üretim alanlarında enfeksiyon oluşturan virüslerin saptanması. Anadolu Tarım Bilimleri Dergisi, 24(2): 67-75.

Fidan, H., Güllü, M., Hekimhan, H., Gözüaçık, C., Konuksal, A., Akerzurumlu, E., 2014. Kuzey Kıbrıs Türk Cumhuriyeti tahıl üretim alanlarında Arpa sarı cücelik virüsü (Barley yellow dwarf virus, BYDV)'nün tespiti ve virüs-vektör ilişkilerinin belirlenmesi. Türkiye V. Bitki Koruma Kongresi, 35 Şubat, Antalya, 209s

Gaunce, G.M., Bockus W.W., 2015. Estimating yield losses due to barley yellow dwarf on winter wheat in
Kansas using disease phenotypic data. Plant Health Progress, 16(1): 1-6.

Ilbağı H., 2003. Trakya Bölgesinde üretimi yapılan bazı buğday türlerinde verim kayıplarına neden olan viral kökenli enfeksiyonların etmenlerinin tanılanması. Doktora Tezi, Ege Üniversitesi, Fen Bilimleri Enstitüsü, 136 s.

Ilbağı, H., Çıtır, A.,Yorganc1, Ü. 2005. Occurrence of virus infections on cereal crops and their identifications in the Trakya region of Turkey. Journal of Plant Diseases and Protection, 112(4): 313-320.

Ilbağı, H., 2017. Tahıl üretim alanlarında sarı cücelik virüs hastalıkları (Yellow dwarf virus diseases) epidemisi ve mücadelesi. Bitki Koruma Bülteni, 57(3): 317 - 335 .

Irwin M.E., Thresh, J.M., 1992. BYDV epidemiology: A study in ecological complexity. In: Comeau, A., Makkouk, K.(Eds.). BYDV in West Asia and North Africa. Sayce Publishing, Exeter, UK. pp, 3-30.

Kaddachi, I., Souidan, Y., Achouri, D., Cheour, F., 2014. Barley yellow dwarf virus (BYDV): characteristics, hosts, vectors, disease symptoms and diagnosis. International Journal of Phytopathology, 3: 155-163.

Kizılaslan, H., 2004. Dünya'da ve Türkiye'de Buğday Üretimi ve Uygulanan Politikaların Karşılaştırılması GOÜ. Ziraat Fakültesi Dergisi, 21(2): 23-38.

Kennedy, T.F., Connery, J., 2005. Grain yield reductions in spring barley due to barley yellow dwarf virus and aphid feeding. Irish Journal of Agricultural and Food Research, 44: 111-128.

Köklü, G., 2004. Occurrence of cereal viruses on wheat in Tekirdağ, Turkey. Phytoprotection, 85: 19-25.

Krueger, E.N., Beckett, R., Gray, S.M., Miller, W.A., 2013. The complete nucleotide sequence of the genome of Barley yellow dwarf virus-RMV reveals it to be a new Polerovirus distantly related to other yellow dwarf viruses. Frontiers Microbiology, 4: 205.

Ordon, F., Habekuss, A., Kastirr, U., Rabenstein ,F., Kuhne, T., 2009. Virus resistance in cereals: sources of resistance, genetics and breeding. Journal of Phytopathology, 157: 535-545.

Perry, K., Kolb, F., Sammons, B., Lawson, C., Ohm H., 2000. Yiels effects of BYDV in soft red winter wheat. Phytopathology, 90(9): 1043-1048.

Plumb, R.T., Johnstone, G.R., 1995. Cultural, chemical and biological methods for the control of barley yellow dwarf. In: D'Arcy, J.C., Burnett, P.A. (Eds). Barley yellow dwarf. St Paul, MN, APS Press. USA, pp. 307-319.

Pocsai, E., Çıtır, A., İlbağı, H., Köklü, G., Muranyı, I., Vida, G., Korkut Z.K., 2003. Incidence of Barley yellow dwarf viruses, Cereal yellow dwarf virus and Wheat dwarf virus in cereal growing areas of Turkey. Agriculture, 11: 583-591.

Singh, R.P., Burnett, P.A., Albarran, M., Rajaram, S., 1993. Bdv1: a gene for tolerance to barley yellow 
dwarf virus in bread wheats. Crop Science, 33: 231234

Thackraya, D.J., Diggleab, A.J., Blackwell, R.A.C.J., 2009. A simulation model to predict aphid arrival, epidemics of Barley yellow dwarf virus and yield losses in wheat crops in a Mediterranean-type environment. Plant Pathology, 58: 186-202.

Usta, M., Sipahioğlu H.M., Güller A., 2016. Doğu Anadolu Bölgesi'nde buğday üretim alanlarındaki bazı buğday virüslerinin multipleks-RT-PCR yöntemi ile araştırılması ve moleküler karakterizasyonu. Uluslararası Katılımlı Türkiye VI. Bitki Koruma Kongresi, 5-8 Eylül, Konya, 669s.

Wiese, M.V., 1987. Diseases caused by viruses and virus like agents. Compendium of wheat diseases. The American Phytopatological Society, St. Paul, Minnesota, 66-87. 